\title{
Risso's dolphins (Grampus griseus) in a proposed Marine Protected Area off east Lewis (Scotland, UK), 2010-2017
}

\author{
CAROLINE R. WEIR ${ }^{1,2}$, NICOLA K. HODGINS ${ }^{1}$, SARAH J. DOLMAN ${ }^{1}$ AND ALICE E. M. WALTERS ${ }^{1}$ \\ ${ }^{1}$ Whale and Dolphin Conservation, 38 St Paul Street, Chippenham, Wiltshire SN15 1LJ, UK, ${ }^{2}$ Ketos Ecology, 4 Compton Road, \\ Kingsbridge, Devon TQ7 2BP, UK
}

\begin{abstract}
The coastal waters of east Lewis from the Butt of Lewis to Loch Erisort are a proposed Marine Protected Area (MPA) for Risso's dolphins (Grampus griseus). A total of $100.4 \mathrm{~h}(2006.4 \mathrm{~km})$ of active search effort (Beaufort sea states $\leq 3)$ was collected during 72 dedicated boat surveys between 2010 and 2017 (primarily in August and September) in the southern part of the MPA and south to the Shiant Isles. Forty Risso's dolphin sightings and $24.1 \mathrm{~h}$ of encounter effort were recorded, predominantly along the southern and eastern Eye Peninsula in 20-40 $\mathrm{m}$ water depths and at distances $<_{1} \mathrm{~km}$ from shore. Group size ranged from one to 50 animals (mean $=11.8$ dolphins) and calves occurred in $37.5 \%$ of sightings. A total of 2404 shorebased scans (Beaufort sea states $\leq 3$ ) carried out from Tiumpan Head between September 2011 and December 2017 resulted in $271(11.3 \%)$ 'dolphin-present' scans. Dolphins were present year-round, with a seasonal increase between May and October. 'Calf-present' scans only occurred between April and October. Photo-identification images from 28 boat surveys produced a minimum population size of 117 animals. There was evidence of high inter-and intra-annual site fidelity, with individual dolphins photographically captured in up to six of the eight survey years, and between two and seven capture dates being recorded for over $45 \%$ of individuals within most years. The combined datasets support the importance of east Lewis for Risso's dolphins, and recommendations are made for ongoing monitoring of dolphin occurrence throughout the wider MPA.
\end{abstract}

Keywords: Atlantic Ocean, calves, distribution, photo-identification, relative abundance, site fidelity, The Minch

Submitted 12 February 2018; accepted 12 June 2018; first published online 18 February 2019

\section{INTRODUCTION}

The Risso's dolphin (Grampus griseus) is a widespread species that occurs in all major ocean basins between latitudes of $\sim 64^{\circ} \mathrm{N}$ to $45^{\circ} \mathrm{S}$ (Jefferson et al., 2014). The species demonstrates a strong preference for mid-temperate waters of the continental shelf and slope at latitudes of between $30^{\circ}$ and $45^{\circ}$ in both hemispheres. Nevertheless, some areas of concentration do occur at higher latitudes. One such region comprises North-east Atlantic shelf $(<200 \mathrm{~m}$ depth $)$ waters around the $\mathrm{UK}$ and Ireland $\left(50-61^{\circ} \mathrm{N}\right)$, where the warming influence of the Gulf Stream provides suitable habitat (Jefferson et al., 2014).

Within the UK, the Risso's dolphin is distributed primarily along the Atlantic seaboard and is comparatively uncommon in the North Sea and eastern English Channel. Most UK sightings originate from shelf waters around the Shetland Islands, the Outer Hebrides, the Irish and Celtic Seas, and the western portion of the English Channel (Evans et al., 2003; Reid et al., 2003). Risso's dolphins are observed year-round in UK waters; however, sightings are most frequently reported in shelf waters between May and September (Evans et al., 2003; Reid et al., 2003). While survey coverage in deep-waters along the shelf edge is much lower than over the shelf, sightings have

Corresponding author:

C.R. Weir

Email: caroline.weir@ketosecology.co.uk been reported between July and November (Weir et al., 2001). Although the Risso's dolphin is widely distributed in the UK, it is not considered to be especially numerous. Large-scale cetacean abundance surveys were carried out in European Atlantic waters during 1994 and 2005 (SCANS-I and SCANS-II; Hammond et al., 2013), but recorded too few sightings to generate an abundance estimate for Risso's dolphins. A similar survey in 2016 generated an estimate of 11,069 animals $(\mathrm{CV}=0.51)$ for European shelf waters (SCANS-III: Hammond et al., 2017).

The coastal waters of the Outer Hebrides (north-west Scotland: Figure 1) comprise a notable area of concentration of Risso's dolphin sightings in the UK, particularly the eastern coast of the islands within The Minch, the Little Minch and the Sea of Hebrides (Evans et al., 2003; Reid et al., 2003). In particular, sightings have been recorded over several decades along the east and north coasts of the Isle of Lewis around the Eye Peninsula and Butt of Lewis (e.g. Gill \& Atkinson, 1996; Atkinson et al., 1999; Weir et al., 2001; Evans et al., 2003; Reid et al., 2003), indicating that this area represents a persistent 'hotspot' of occurrence. Targeted surveys were carried out around the Eye Peninsula during the summers of 1995 and 1996, identifying Branahuie Bay, Tiumpan Head and Kebock Head as favoured locations (Gill \& Atkinson, 1996). Limited winter effort in 1995 also produced sightings (Gill \& Atkinson, 1996), suggesting a yearround occurrence in the area. A photo-identification study identified at least 142 Risso's dolphins, with 52 animals 


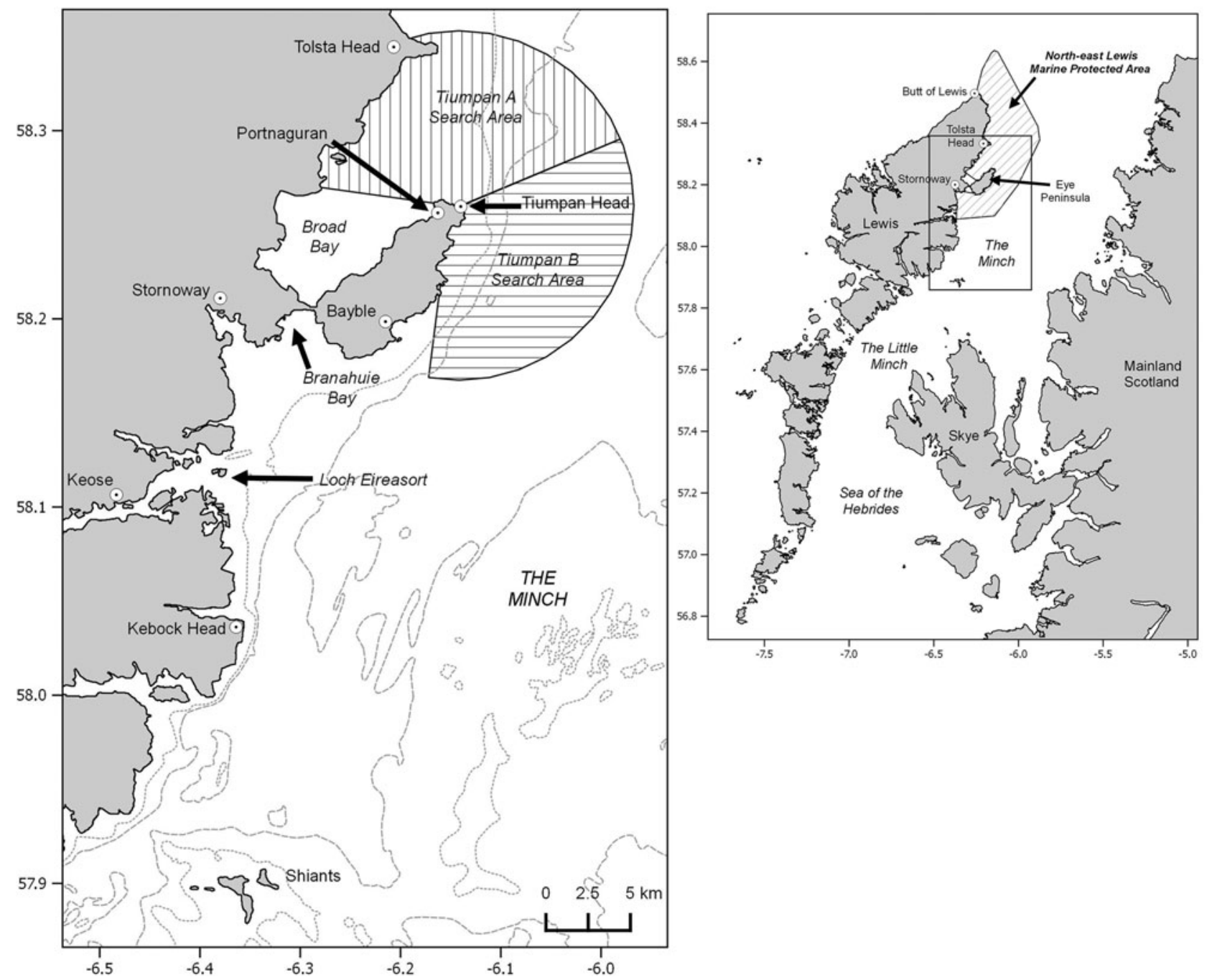

Fig. 1. Map of the study area, shown also in a box in relation to the wider region of north-west Scotland. Bathymetry is $50 \mathrm{~m}$ (dot) and $100 \mathrm{~m}$ (dash).

photographically recaptured between the summers of 1995 and 1996 (Atkinson et al., 1999).

In recognition of their apparent importance for Risso's dolphins, the waters along the north-east coast of the Isle of Lewis from the Butt of Lewis to Loch Erisort were identified under The Marine (Scotland) Act 2010 as a proposed nature conservation Marine Protected Area (MPA) to protect identified priority marine features (PMFs) or nationally important marine habitats and species in Scottish territorial waters. Risso's dolphins are a proposed protected feature of the North-east Lewis Marine Protected Area (NEL-MPA), with the provisional MPA boundaries encompassing part of an area predicted to persistently support above average dolphin densities (Paxton et al., 2014), and also incorporating sand eel (Ammodytes spp.; another qualifying feature) habitat (Figure 1). The NEL-MPA is currently recognized as a proposed MPA, having been fully assessed against the Scottish MPA Selection Guidelines (SNH, 2014a).

Since 2010, Whale and Dolphin Conservation (WDC) has conducted small-boat cetacean surveys along the east coast of the Isle of Lewis, with the aim of collecting distribution and photo-identification data on Risso's dolphins. A complementary year-round temporal dataset has been generated by the citizen science WDC Shorewatch project at Tiumpan Head on the Eye Peninsula. Here, these data sources are assessed to examine aspects of Risso's dolphin occurrence in the proposed NEL-MPA during the most recent decade as a comparison with data from the 1990 s (e.g. Gill \& Atkinson, 1996, Atkinson et al., 1999, Evans et al., 2003). We present new data on the spatial distribution, seasonal occurrence and inter-annual fidelity of Risso's dolphins off east Lewis, with the overall objectives of demonstrating persistent use of the site over time (by both individuals and by the species) and providing updated information in further support of the NEL-MPA designation. We also evaluate the outputs of the survey work with respect to generating the robust data needed to inform conservation management of the species, and make recommendations for ongoing monitoring programmes.

\section{MATERIALS AND METHODS}

\section{Study area}

The study area comprised the waters along the east coast of Lewis, extending from Tolsta Head in the north to the Shiant Isles in the south (Figure 1). The coastal waters along 
the $11 \mathrm{~km}$ long Eye Peninsula, located to the east of Stornoway, were the main focus area for the boat and shorebased work. The study area overlapped with the southern portion of the proposed NEL-MPA (Figure 1).

\section{Boat surveys}

Dedicated boat-based dolphin surveys were carried out between 2010 and 2017 (Table 1), primarily using a variety of small $(\leq 6.5 \mathrm{~m})$ motor boat platforms at $\sim 2 \mathrm{~m}$ eye height. A larger vessel (20 m) was used for three surveys in 2017, providing an eye height of $\sim 6 \mathrm{~m}$. Boat survey speeds were typically $15-20 \mathrm{~km} \mathrm{~h}^{-1}$. The surveys departed from various harbours including Bayble and Portnaguran on the Eye Peninsula, Keose in Loch Erisort, and Stornoway. The route usually followed a similar outward and return track to the Eye Peninsula although a small number of trips surveyed a large loop that included inshore and offshore legs.

Surveys only commenced when conditions were forecast to be suitable for the visual detection of cetaceans (Beaufort sea state $\leq 3$, low swell height and good visibility). Between two and three observers (including the boat driver) maintained a continuous visual watch for cetaceans whenever the vessel was underway using naked eye scans. A GPS was used to $\log$ the positions of cetacean sightings and other events. From 2012, a GPS track was also continuously recorded for most of the dedicated boat surveys (Table 1). Beaufort sea state and effort status were recorded verbally into a dictaphone whenever they changed. Effort status was categorized as: Active Search, when observers were actively looking for cetaceans; Encounter Effort, when observers were working with a group of Risso's dolphins; and Off Effort, when the observers were not searching for cetaceans. Whenever Risso's dolphins were sighted the effort switched to Encounter Effort and standardized data including the time, location, group size and the presence of calves or juveniles were recorded. The definitions of Airoldi et al. (2015) were used to visually classify the individuals as: (1) adults: individuals of about 3-4 m long; (2) juveniles: individuals $\sim 2 / 3$ the length of an adult, usually swimming in association with an adult, but sometimes swimming independently; and (3) calves: individuals $1 / 2$ the length of an adult, in close association with an adult, and swimming regularly beside or slightly behind, an adult.

When dolphin behaviour, weather and logistical constraints permitted, photo-identification data (see Würsig \&
Jefferson, 1990) were collected using Canon DSLR cameras fitted with a 100-400 mm zoom lens. Photographic effort concentrated mainly on the dorsal fin and attempts were made to photograph both sides of any animal that surfaced within suitable proximity to the boat and irrespective of perceived dorsal fin distinctiveness. All photo-identification work was carried out under a Research Licence from Scottish Natural Heritage (SNH).

\section{Shore-based surveys}

A WDC Shorewatch citizen science project commenced at Tiumpan Head during 2011, using trained volunteers following a scan sampling protocol for cetaceans. The vantage point was located $63 \mathrm{~m}$ above sea level and provided an expansive view $\left(>300^{\circ}\right)$ of Broad Bay and open waters in The Minch. Two separate sites were defined (Tiumpan A and Tiumpan B), each consisting of a non-overlapping sea area of $\sim 150^{\circ}$ (Figure 1).

A 10-min cetacean scan of each site was conducted by a single observer and consisted of two 4-min scans across the study area (to the horizon) using $7 \times 50$ Opticron Marine- 3 binoculars, interspersed by two 1 -min scans with the naked eye. Standardized data were recorded including the date, time, Beaufort sea state, visibility and the details of cetacean sightings (e.g. time, bearing, distance and species identification). A minimum count was made in lieu of group size, with observers logging the maximum number of dorsal fins seen at the surface at any one time during the encounter rather than trying to estimate the total number of animals present. Group composition was logged as adults and calves, and consequently any noticeably smaller individuals (including juveniles) were recorded as 'calves'.

\section{DATA ANALYSIS}

\section{Boat surveys}

Each encounter with a new dolphin group on a particular date was defined as a primary sighting. Encounters were classified as re-sightings when photo-identification confirmed that the majority of individuals in the group had been recorded earlier on the same survey. The group size of each sighting used for analysis was either the best visual estimate or the

Table 1. Summary of dedicated dolphin boat-based surveys off the east coast of Lewis between 2010 and 2017.

\begin{tabular}{|c|c|c|c|c|c|c|c|c|c|}
\hline \multirow[t]{2}{*}{ Year } & \multicolumn{6}{|c|}{ Total surveys } & \multicolumn{3}{|c|}{ Surveys with GPS data } \\
\hline & $N$ & May & June & August & September & October & $N$ & Total search effort $(\mathbf{h} / \mathbf{k m})$ & Search effort in Beaufort $\leq 3(\mathrm{~h} / \mathrm{km})$ \\
\hline 2010 & 7 & - & - & 3 & 4 & - & o & - & - \\
\hline 2011 & 9 & - & - & 5 & 4 & - & o & - & - \\
\hline 2012 & 10 & - & - & 3 & 5 & 2 & 5 & $15.9 / 288.7$ & $8.1 / 136.1$ \\
\hline 2013 & 12 & 2 & - & 1 & 8 & 1 & 8 & $17.3 / 425.7$ & $16.1 / 389.4$ \\
\hline 2014 & 11 & - & 2 & - & 8 & 1 & 10 & $22.1 / 403.4$ & $22.1 / 403.4$ \\
\hline 2015 & 9 & - & 3 & 5 & 1 & - & 7 & $18.4 / 364.1$ & $17.2 / 339.9$ \\
\hline 2016 & 6 & - & - & 1 & 5 & - & 6 & $15.9 / 376.0$ & $13.0 / 308.4$ \\
\hline 2017 & 8 & - & - & - & 8 & - & 8 & $25.0 / 443.2$ & $23.9 / 429.1$ \\
\hline Total & 72 & 2 & 5 & 18 & 43 & 4 & 44 & $114.6 / 2301.1$ & $100.4 / 2006.4$ \\
\hline
\end{tabular}


minimum photo-identification group size (whichever was highest). When photo-identification resulted in more individuals than had been accounted for visually, the additional animals were allocated to the 'unaged' category for the group composition analysis. Only primary sightings were used for group size analysis in order to avoid overrepresentation of particular group sizes or age compositions from the inclusion of re-sightings.

All boat-based survey effort and sightings were mapped using Quantum Geographic Information System (QGIS) 2.8.3 (www.qgis.org). A polygon of $500 \mathrm{~m}$ grid cells was created in QGIS and used to create presence-absence and relative abundance (individuals $\mathrm{km}^{-1}$ ) maps, using only those data subsets where a GPS track was available (see Table 1). For presence-absence mapping, the initial sighting positions of Risso's dolphins $(2010-2017)$ and the locations of all dolphin encounter effort (2012-2017) were used to indicate dolphin presence in a grid cell, while search effort collected in Beaufort sea states $\leq 3$ was used to indicate 'absence'. For relative abundance, only active search effort in Beaufort sea states $\leq 3$ and associated sightings were used. The total amount of survey effort in each $500 \mathrm{~m}$ grid cell was calculated in QGIS. Both sightings and resightings were used in the relative abundance calculations, since the outward and inward survey route usually comprised repeated passes across the same area and omitting re-sightings on the return leg would have falsely reduced the resulting values.

Information on water depth was obtained from the Digibath contour data set, which was interpolated into a continuous $0.5 \mathrm{~km}$ resolution grid in QGIS. The distance of sightings and effort locations from the coast were measured from a high-resolution shoreline shapefile (GADM database of Global Administrative Areas) using a QGIS plugin.

\section{Shore-based surveys}

Initial evaluation revealed that two observers accounted for $70 \%$ of the total scans and the majority of Risso's dolphin sightings from Tiumpan Head between 2011 and 2017. To minimize effects from inter-observer variation, only data from those observers were included in the analysis. The potential impacts of weather conditions on dolphin detection rate were reduced by only including scans conducted in Beaufort sea states $\leq 3$ and in visibility of at least $6 \mathrm{~km}$. Any scans that commenced within 50 min of completion of a previous scan were removed. Sightings were only accepted as Risso's dolphins when species identification confidence was $\geq 75 \%$.

Each 10-min scan was graded for the presence or absence of Risso's dolphins and for the presence or absence of calves. The proportion of dolphin-positive scans was calculated from the total number of scans carried out at each site per year and per month to assess temporal patterns.

\section{Photo-identification}

Similar to other studies, individual Risso's dolphins off Lewis were catalogued via distinctive features that included dorsal fin nicks, notches and amputations, and the pattern of scarring on and around the dorsal fin (Hartman et al., 2008,
2014; Airoldi et al., 2015). To ensure an equal likelihood for recapturing individuals over the 8-year study duration, the target area used during cataloguing was the dorsal fin and the region of flank located immediately forward of, behind and below the dorsal fin. This area is consistently available when a Risso's dolphin surfaces, whereas scar patterns around the head, lower flank and tailstock are not consistently visible at the surface. Additionally, the scar pattern on the dorsal fin is more stable than that on the body (Hartmann et al., 2013), and thus more likely to remain recognizable over the long term.

The best-available left- and right-side images for each individual in each year were selected, and cropped to a standardized size around the target area for cataloguing. Two suspected hybrids between Risso's dolphins and bottlenose dolphins (Tursiops truncatus) were included in the catalogue due to their greater morphological similarity to the former species (see Hodgins et al., 2014). Following initial cataloguing (using standardized methods: Würsig \& Jefferson, 1990), the photographic quality (PQ) and distinctiveness value (DV) of each entry was independently graded using adapted versions of the criteria and examples provided by Airoldi et al. (2015). The quality control grading was carried out separately for each annual catalogue, since DV may alter over time and the PQ for each individual (and side) varied between years.

Each animal was assigned a DV based on permanent marks along the fin edges (DV1-3, corresponding to deep, moderate or small nicks) or on scar patterns in the target area (DV4A, $4 \mathrm{~B}$ and 5 , corresponding to heavy, moderate or low scarring). The lowest value was used; i.e. if an animal had both moderate nicks and heavy scarring it was allocated to $\mathrm{DV}_{2}$ rather than DV4A. A final DV score was allocated to each dolphin in each year based on the majority opinion from three sets of observer scores.

Images were graded as good (1), moderate (3) or poor (5) for four categories of $\mathrm{PQ}$, comprising focus, exposure, angle and visibility of the target area in the frame (cf. Airoldi et al., 2015). Each observer's scores for each image were summed to produce a total PQ value for every catalogued image. The total PQ values from four observers were then averaged to produce a final overall $P Q$ value for each image (left and right sides being graded separately) of: PQ1: 4.06.5 (good), PQ2: 7.0-9.5 (moderate); PQ3: 10.0-12.5 (poor); and PQ4: 12.5-20.0 (very poor). Additionally, if two or more observers graded an image as poor in any of the four PQ categories then the image was immediately classified as PQ4 and considered unsuitable for further analysis (as per Airoldi et al., 2015).

The minimum population size (MPS) was calculated for each year and for the entire study, and was defined as the total number of distinctive Risso's dolphins photographically captured in the east Lewis study area (i.e. no genetic or absolute abundance implications). The MPS comprised the sum of: (1) all permanently marked animals $\left(\mathrm{DV}_{1}-3\right.$; which should be identifiable from both sides), and (2) all animals identified from scar patterns ( $\left.\mathrm{DV}_{4}-5\right)$ on one side (left or right, depending which was highest in each year). Calculations of MPS were made using subsets of images of varying PQ. The minimum photo-identification group size was calculated in the same manner as the MPS, using either the left or right sides of DV4-5 animals depending on which had highest occurrence within each group. 


\section{RESULTS}

\section{Boat surveys}

Seventy-two dedicated boat surveys for dolphins were carried out between 2010 and 2017. The temporal distribution of the boat surveys showed strong seasonality, with the vast majority $(\mathrm{N}=61 ; 85 \%)$ carried out in August and September (Table 1) The total number of surveys also varied between years, with most carried out between 2012 and 2014. A GPS track log was available for 44 of the surveys carried out between 2012 and 2017 (Table 1). A total of $138.7 \mathrm{~h}$ of data collection occurred during the 44 surveys, of which $114.6 \mathrm{~h}$ comprised active search effort and $24.1 \mathrm{~h}$ comprised encounter effort. Of the total active search effort, $100.4 \mathrm{~h}(2006.4 \mathrm{~km} ; 87.6 \%)$ occurred in Beaufort sea states $\leq 3$ (Table 1 ), and was suitable for relative abundance analysis.

The search effort was concentrated in the area between Loch Erisort and Tiumpan Head (Figure 2A), reflecting the main dolphin survey route. Moderate amounts of search effort were collected in the approaches to Stornoway Harbour and Branahuie Bay, and along the coast south of Loch Erisort to Kebock Head. Some search effort occurred as far south as the Shiant Isles, offshore to $\sim_{15} \mathrm{~km}$ from the coast and north into Broad Bay.
A total of 32 primary sightings of Risso's dolphins were observed during the dedicated boat surveys, with an additional eight re-sightings of dolphin groups (Table 2). Sightings occurred only in August and September, and there was inter-annual variation in the number of sightings (Table 2). The initial sighting locations were predominantly distributed all around the south and east coasts of the Eye Peninsula (Figure $2 \mathrm{~B}$ ) with the only exceptions being a sighting $1.8 \mathrm{~km}$ off Tolsta Head at the northern limit of the study area, and one $\sim 3 \mathrm{~km}$ from the coast to the north-east of Loch Erisort. No Risso's dolphins were recorded in the southern portion of the study area between Loch Erisort and the Shiant Isles.

A total of $24.1 \mathrm{~h}$ of Risso's dolphin encounter effort was recorded during dedicated surveys, with the highest amounts occurring in 2014 and 2016 (Table 2). Presencepositive grid cells spanned the entire east coast of Lewis from Branahuie Bay to north of the Eye Peninsula (Figure $2 \mathrm{~B}$ ). A total of 27 primary and re-sightings were associated with the $2006.4 \mathrm{~km}$ of active search effort recorded during 44 surveys from 2012 to 2017 (Table 1), producing relative abundance values of 0.554 to 6.647 individuals $\mathrm{km}^{-1}$ across 24 grid cells. The southern region of the Eye Peninsula produced the consistently highest relative abundance values (Figure $2 \mathrm{C}$ ).
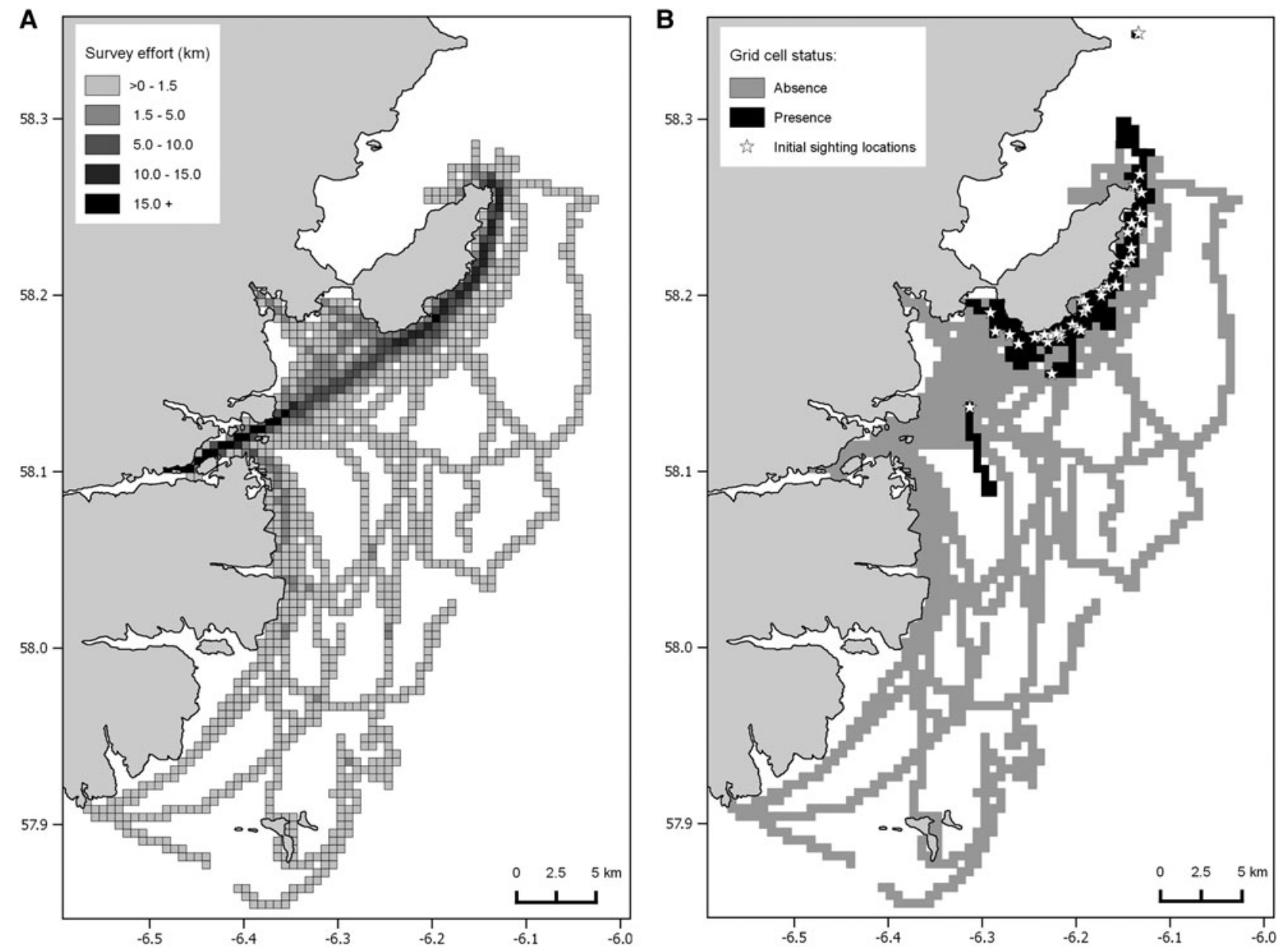

Fig. 2. The spatial distribution ( $500 \mathrm{~m}$ grid cells) of: (A) all search effort in Beaufort sea states $\leq 3$; (B) initial sighting locations of Risso's dolphins ( $\mathrm{N}=39$; 1 sighting lacked a position) and the presence-absence grid cell occurrence; and (C) Risso's dolphin relative abundance. 


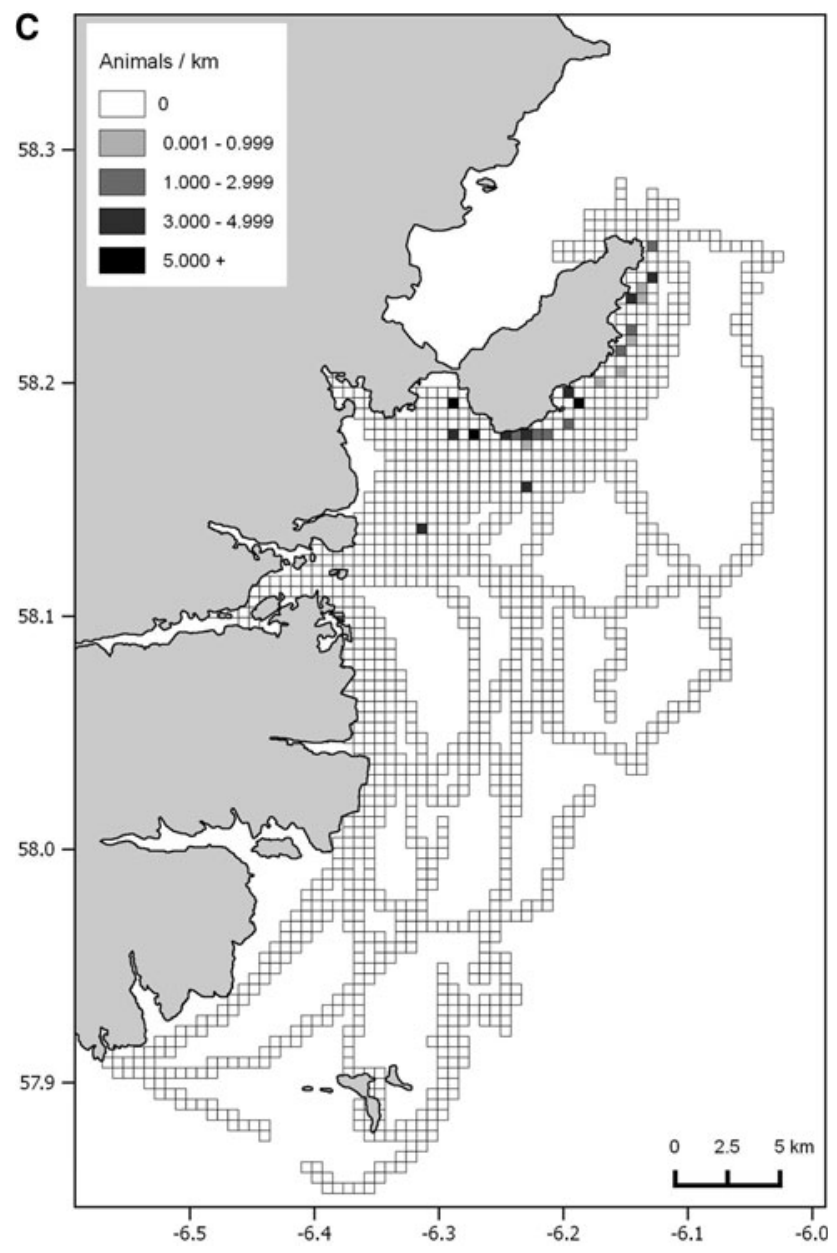

Fig. 2. Continued

The group size during primary boat-based sightings ranged from 1 to 50 animals, with a mean of 11.8 dolphins $(\mathrm{N}=32, \mathrm{SD}=9.0$, median $=11.0$ animals $)$. The majority of groups $(\mathrm{N}=25,78.1 \%)$ comprised $\leq 15$ individuals. The 50 animals observed on 17 September 2017 was more than double the size of any other group recorded during the study. Calves were recorded in 12 (37.5\%) of the 32 sightings, with juveniles confirmed in an additional five groups. Group size was significantly higher when calves were present (median $=13.5$ vs 7.0, MannWhitney $U$ test, $U=265.0, P=<0.01$ ) and in groups containing calves and/or juveniles (median $=14.0 \mathrm{vs}$ 6.0, Mann-Whitney $U$ test, $U=158.0, P=<0.001)$ than in adult-only groups.

An analysis of effort and sightings according to water depth and distance from shore indicated that both the highest Risso's dolphin sighting rate and the greatest amount of encounter effort were recorded in water depths of 20 to $40 \mathrm{~m}$ and within $1 \mathrm{~km}$ of the coast (Table 3 ).

\section{Shore-based surveys}

A combined total of 2404 scans was carried out at Tiumpan Head between September 2011 and December 2017, comprising 1243 scans at Tiumpan A and 1161 scans at Tiumpan B. Risso's dolphins were present during 271 (11.3\%) scans. The number of scans carried out from the combined sites has grown over time, with only 14 in 2011 , increasing to over 200 per year between 2013 and 2015, and reaching over 700 per year in 2016 and 2017. The number of scans also varied seasonally, with most (73.6\%) occurring over the summer between May and October and only $7.2 \%$ in the winter months between December and February (Figure 3).

Risso's dolphins were present year-round at the sites but showed seasonal peaks, with the proportion of dolphinpositive scans varying from 0.112 to 0.155 at Tiumpan A between May and August and from 0.121 to 0.188 at Tiumpan B between May and October (Figure 3). Much lower proportions of dolphin-positive scans were recorded from December to April. Calf-positive scans were only recorded between April and October, with peaks during July (both areas), August (Tiumpan B) and October (both areas).

\section{Photo-identification}

Photo-identification images of Risso's dolphins were obtained on 28 boat surveys, including 27 dedicated dolphin surveys and one non-dedicated survey. A total of 131 dolphins was catalogued between 2010 and 2017, comprising 94 animals photographed on both sides, 16 left-side only and 21 rightside only. Between three and 39 dolphins were catalogued each year (Table 4 ).

The overall MPS of Risso's dolphins photographically captured in the study area from 2010 to 2017 was 117 animals using images of all quality and 100 animals using images of PQ1-2 only (Table 4 ). The cumulative rate of discovery of

Table 2. Summary of Risso's dolphin encounters recorded during 72 dedicated dolphin boat-based surveys between 2010 and 2017.

\begin{tabular}{|c|c|c|c|c|c|c|}
\hline \multirow[t]{2}{*}{ Year } & \multicolumn{3}{|c|}{ Total primary sightings (re-sightings) } & \multicolumn{3}{|c|}{ Total encounters ${ }^{a}$} \\
\hline & $N$ & August & September & With GPS encounter effort & Total encounter effort (min) & With photo-ID \\
\hline 2010 & $5(3)$ & $3(2)$ & $2(1)$ & - & - & 5 \\
\hline 2011 & 1 & & 1 & - & - & 1 \\
\hline 2012 & 2 & 1 & 1 & 1 & 0.5 & 2 \\
\hline 2013 & $3(1)$ & - & $3(1)$ & 3 & $3 \cdot 3$ & 3 \\
\hline 2014 & $7(1)$ & - & $7(1)$ & 7 & 6.8 & 7 \\
\hline 2015 & $5(1)$ & $4(1)$ & 1 & 5 & 3.5 & 4 \\
\hline 2016 & $6(2)$ & & $6(2)$ & 6 & 7.8 & 6 \\
\hline 2017 & 3 & - & 3 & 3 & 2.1 & 1 \\
\hline Total & $32(8)$ & $8(3)$ & $24(5)$ & 25 & 24.1 & 29 \\
\hline
\end{tabular}

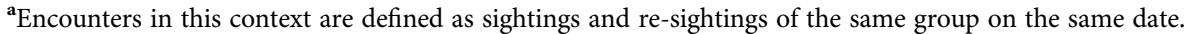


Table 3. Percentage of search ( $100.4 \mathrm{~h}$ in Beaufort sea states $\leq 3$ ) and encounter effort $(24.9 \mathrm{~h})$, and Risso's dolphin sighting rate (sightings $\mathrm{h}^{-1}$ search effort), according to water depth and distance from shore.

\begin{tabular}{lclc}
\hline Habitat category & $\begin{array}{c}\text { Search } \\
\text { effort (h) }\end{array}$ & Sightings/h & $\begin{array}{c}\text { Encounter } \\
\text { effort (h) }\end{array}$ \\
\hline Water depth (m) & & & \\
$\quad<10$ & 9.9 & 0.101 & 2.0 \\
$10-19.9$ & 12.0 & 0.331 & 10.6 \\
$20-29.9$ & 15.7 & 0.824 & 27.3 \\
$30-39.9$ & 22.4 & 0.711 & 40.2 \\
$40-49.9$ & 11.1 & 0.269 & 10.4 \\
$50-74.9$ & 10.5 & 0.095 & 4.0 \\
$75-99.9$ & 4.5 & 0 & 3.8 \\
$100-124.9$ & 10.5 & 0.095 & 1.9 \\
$125+$ & 3.3 & 0 & 0 \\
Distance from shore $(\mathrm{km})$ & 63.9 & 0.545 & 76.1 \\
$<1.0$ & 25.8 & 0.154 & 23.9 \\
$1.0-4.9$ & 8.0 & 0 & 0 \\
$5.0-9.9$ & 2.2 & 0 & 0 \\
$10.0-15.9$ & & & \\
\hline
\end{tabular}

new individuals increased continuously over the study period, and was particularly high in 2016 (more than double that of other years: Figure 4).

The annual MPS using images of PQ1-2 (as required for mark-recapture analysis: Airoldi et al., 2015) varied from three animals (2012) to 32 animals (2016), with a mean of 18.5 individuals per year over the 2010 to 2017 study period $(\mathrm{N}=8, \mathrm{SD}=9.7$, median $=20.5:$ Table 4$)$.

Although the DV of most of the catalogued dolphins remained constant over the study duration, changes in DV were recorded for six individuals. These changes comprised three animals that acquired new nicks and three where the scarring level changed from moderate $\left(\mathrm{DV}_{4} \mathrm{~B}\right)$ to heavy (DV4A) scarring. The DV of catalogued individuals remained at similar proportions in the datasets for images of PQ1-4, PQ1-2 and PQ1, with the exceptions of $\mathrm{DV}_{3}$ and $\mathrm{DV}_{5}$ (Figure 5). When only good-quality images were considered the proportion of $\mathrm{DV}_{3}$ animals increased from $26.0 \%$ $\left(\mathrm{DV}_{1}-4\right)$ to $36.1 \%\left(\mathrm{DV}_{1}\right)$ (Figure 5). In contrast, the proportion of DV 5 animals decreased strongly from $16.8 \%\left(\mathrm{DV}_{1}-4\right)$ to $4.2 \%\left(\mathrm{DV}_{1}\right)$.
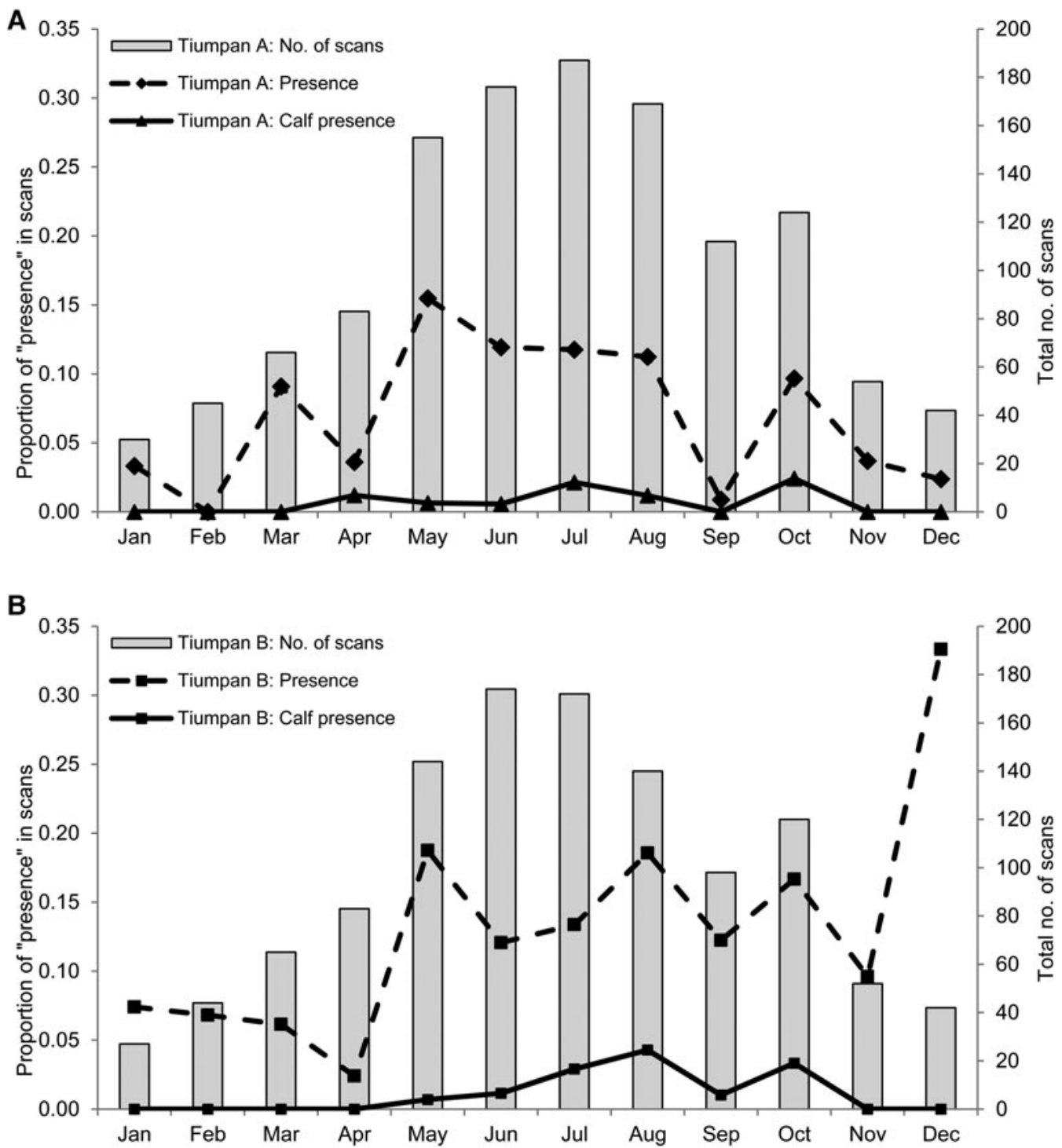

Fig. 3. Seasonal distribution of shore-based 10-min scans and associated 'Risso's dolphin present' and 'calf present' scans recorded by two observers at (A) Tiumpan A; and (B) Tiumpan B. 
Table 4. Minimum population size (MPS) of Risso's dolphins from boat-based photo-identification surveys off east Lewis between 2010 and 2017 , using images of varying Photographic Quality (PQ).

\begin{tabular}{|c|c|c|c|c|c|c|c|}
\hline \multirow[t]{2}{*}{ Year } & \multirow[t]{2}{*}{ No. of photo-ID surveys ${ }^{a}$} & \multirow[t]{2}{*}{ Total dolphins catalogued } & \multicolumn{3}{|c|}{$\begin{array}{c}\text { MPS }(\mathrm{L}=\text { left side majority } \\
\mathrm{R}=\text { right side majority } \\
\mathrm{E}=\text { equal sides })\end{array}$} & \multicolumn{2}{|c|}{$\begin{array}{l}\text { Animals for which } \mathrm{PQ}_{1} \\
\text { images were available }\end{array}$} \\
\hline & & & PQ1 & PQ1-2 & PQ1-4 & $\%$ of PQ1-2 & $\%$ of $P Q 1-4$ \\
\hline 2010 & 5 & 30 & $9(\mathrm{~L})$ & $26(\mathrm{E})$ & $30(\mathrm{E})$ & 34.6 & 30.0 \\
\hline 2011 & 1 & 15 & $3(\mathrm{R})$ & $10(\mathrm{R})$ & $14(\mathrm{~L})$ & 30.0 & 21.4 \\
\hline 2012 & 2 & 3 & $2(\mathrm{~L})$ & $3(\mathrm{~L})$ & $3(\mathrm{~L})$ & 66.7 & 66.7 \\
\hline 2013 & 3 & 20 & $5(\mathrm{R})$ & $19(\mathrm{R})$ & $19(\mathrm{E})$ & 26.3 & 26.3 \\
\hline 2014 & 7 & 31 & $4(\mathrm{E})$ & $25(\mathrm{R})$ & $29(\mathrm{R})$ & 16.0 & 13.8 \\
\hline 2015 & 5 & 26 & $4(\mathrm{R})$ & $22(\mathrm{E})$ & $26(\mathrm{R})$ & 18.2 & 15.4 \\
\hline 2016 & 4 & 39 & $26(\mathrm{R})$ & $32(\mathrm{~L})$ & $34(\mathrm{E})$ & 81.3 & 76.5 \\
\hline 2017 & 1 & 22 & $3(\mathrm{R})$ & $11(\mathrm{R})$ & $18(\mathrm{~L})$ & 27.3 & 16.7 \\
\hline $2010-2017$ & 28 & 131 & $54(\mathrm{R})$ & $100(\mathrm{R})$ & $117(\mathrm{R})$ & 54.0 & 46.2 \\
\hline
\end{tabular}

${ }^{a}$ Defined as boat-based surveys on which photo-identification images were obtained. In 2015 this included photo-identification images taken during one non-dedicated boat survey.

Of the total 131 catalogued dolphins, the majority $(\mathrm{N}=$ $105 ; 80.2 \%)$ were photographically captured in only one year. This proportion decreased slightly to $78.7 \%$ when images of only PQ1-2 were used. Twenty-six individuals (19.8\%) were captured in more than one year, comprising: 2 years $(\mathrm{N}=13), 3$ years $(\mathrm{N}=2), 4$ years $(\mathrm{N}=8), 5$ years $(\mathrm{N}=1)$ and 6 years $(\mathrm{N}=2)$. Four individuals captured during the first year (2010) were also recorded during the two most recent years of the study (2016 or 2017), confirming long-term use of the area. Photographs taken opportunistically off the Eye Peninsula during 2005 (CR Weir, unpublished data) support an even longer occurrence of four individuals, with re-sightings recorded during the dedicated boat surveys after periods of $8,10,11$ and 12 years respectively.

There was evidence that an individual's DV affected the likelihood of annual recapture. All poorly marked animals $\left(\mathrm{DV}_{5} ; \mathrm{N}=22\right)$ were recorded in only one year. Of the moderately marked individuals $(\mathrm{N}=67), 16.4 \%$ were recorded in two $(9.0 \%)$ or three $(7.5 \%)$ years (Figure 6). A total of $35.7 \%$ of well-marked individuals (DV1, DV 2 and $\mathrm{DV}_{4} \mathrm{~A}$; $\mathrm{N}=42$ ) were captured in more than one year, and comprised the majority of the recaptures over the study duration.
The within-season capture rates indicated that many individuals remained off the coast of Lewis for prolonged periods, with between two and seven capture dates being recorded for over $45 \%$ of individuals in most years (Table 5). In 2014, three individuals were captured on all seven survey dates between 14 and 29 September, and a further seven animals were captured on six dates. In 2013 the majority of individuals $(\mathrm{N}=12)$ were recorded on all three of the survey dates that year (Table 5). In all years except 2015 (which differed by only one day) the maximum interval between the first and last capture date of individual dolphins was identical to the maximum intervals between photo-identification surveys indicating that animals were present throughout the period of available effort (Table 5).

\section{DISCUSSIDN}

\section{Conservation implications}

The scientific evidence-base for the identification of the Risso's dolphin component of the proposed NEL-MPA comprised multiple datasets originating between 1994 and 2012

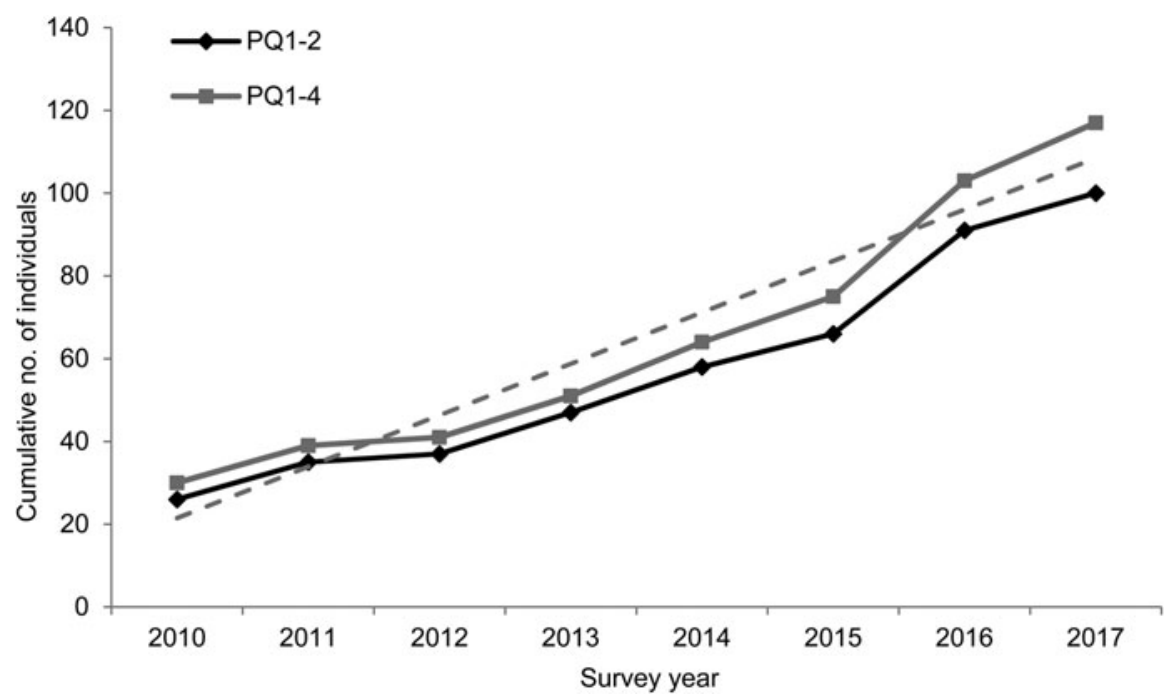

Fig. 4. Annual cumulative rate of discovery ('discovery curve') of photo-identified Risso's dolphins for images of $P Q 1-2(N=100)$ and $P Q 1-4$ ( $N=117)$ off east Lewis between 2010 and 2017. 


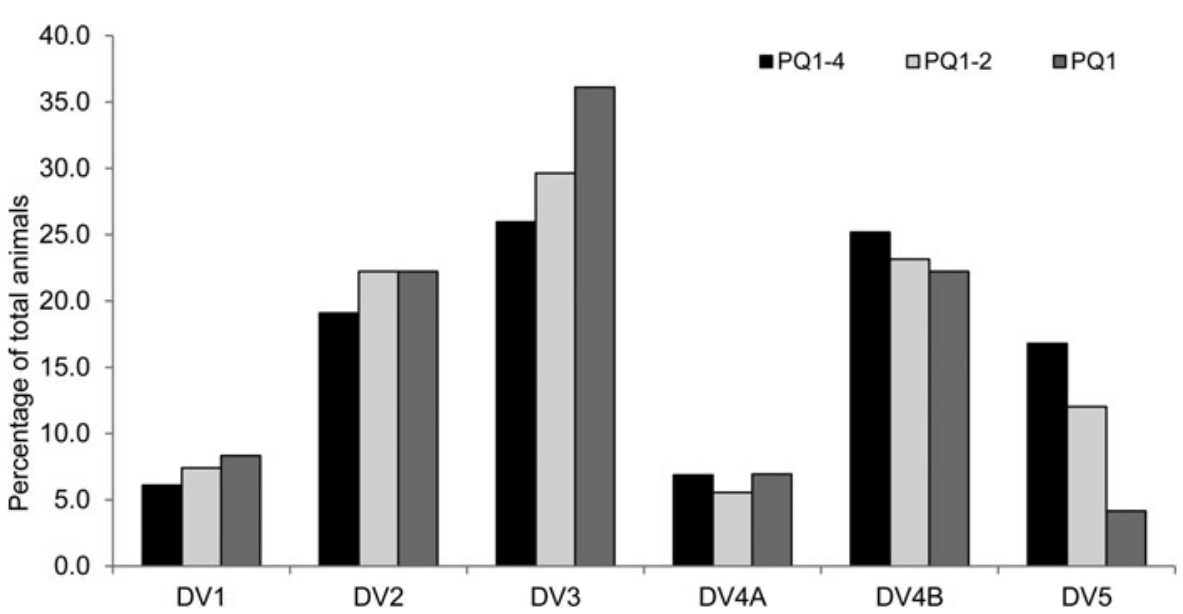

Fig. 5. Proportions of individual Risso's dolphin Distinctiveness Values (DVs) using images of Photographic Quality (PQ) $1-4$ (all quality), PQ1-2 (good and moderate quality) and PQ1 (good quality).

(SNH \& JNCC, 2012; Paxton et al., 2014). The data presented in this paper extend the existing evidence-base to incorporate the most recent years, and support an ongoing occurrence of Risso's dolphins in the proposed NEL-MPA over multiple decades until at least December 2017.

Within the spatial area covered by the surveys, Risso's dolphins were primarily distributed in nearshore $\left(<_{5} \mathrm{~km}\right)$ waters along the south and east coasts of the Eye Peninsula during the late summer monitoring periods. Only one sighting occurred south of that area (off the entrance of Loch Erisort). The core area used by Risso's dolphins within the study area was located within the proposed NEL-MPA boundaries, although one group of dolphins was tracked across and beyond the MPA southern boundary. However, the current NEL-MPA boundaries do not incorporate most of Branahuie Bay, an area highlighted as a favoured site for Risso's dolphins during the summer/autumn in the 1990 (Gill \& Atkinson, 1996), identified as a moderate-density area in the MPA data assessment (SNH, 2014b), and also used by dolphins during the 20102017 monitoring work (this study). Additionally, Risso's dolphins were tracked to within tens of metres of the cliffs around the southern Eye Peninsula during some encounters, and since the NEL-MPA boundaries do not extend up to the shoreline, those areas are also outside of the proposed MPA. It is therefore recommended that the proposed NELMPA boundaries are revised to include Branahuie Bay and to encompass nearshore waters used by Risso's dolphins around the southern half of the Eye Peninsula.

Evans et al. (2003) reported that Risso's dolphins in UK waters favoured habitat of 50-100 m depth. The boat-based surveys presented here included a reasonable amount of search effort in waters up to $125 \mathrm{~m}$ depth, but dolphins primarily occurred in depths of 20-40 $\mathrm{m}$. Atkinson et al. (1999) suggested that Risso's dolphins may move into deeper offshore waters east of the Eye Peninsula between May and July, and therefore the apparent preference for nearshore shallower waters during this study may be a consequence of the seasonal nature of the survey effort.

Although the timing of boat survey work was strongly biased towards August and September, the WDC Shorewatch dataset

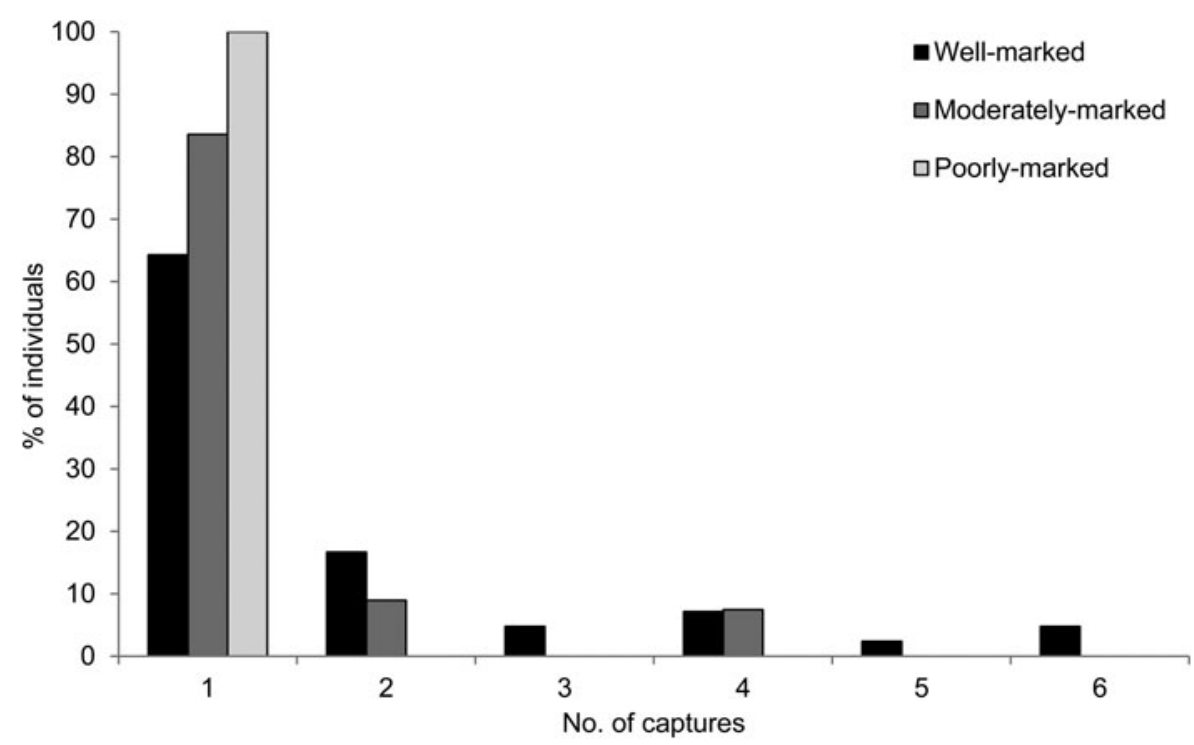

Fig. 6. Proportion of inter-annual photographic 'captures' of distinctive Risso's dolphins $(\mathrm{N}=131)$ according to three categories of Distinctiveness Value (DV): well-marked (DV1, DV2 and DV4A); moderately marked (DV3 and DV4B) and poorly marked (DV5). 
Table 5. Intra-annual encounter dates of Risso's dolphins from years in which more than two boat-based photo-identification surveys occurred off east Lewis.

\begin{tabular}{|c|c|c|c|c|c|c|c|c|c|c|}
\hline \multirow[t]{2}{*}{ Year } & \multirow[t]{2}{*}{$\begin{array}{l}\text { No. unique survey } \\
\text { dates }\end{array}$} & \multirow[t]{2}{*}{$\begin{array}{l}\text { No. of individuals } \\
\text { captured }\end{array}$} & \multirow[t]{2}{*}{$\begin{array}{l}\text { Max. interval (days) from } \\
\text { first to last capture }\end{array}$} & \multicolumn{7}{|c|}{$\begin{array}{l}\text { No. of within-season photographic } \\
\text { captures (\% of individuals) }\end{array}$} \\
\hline & & & & 1 & 2 & 3 & 4 & 5 & 6 & 7 \\
\hline 2010 & 5 & 30 & 24 & 50.0 & 26.7 & 16.7 & 6.7 & 0 & - & - \\
\hline 2013 & 3 & 20 & 23 & 35.0 & 5.0 & 60.0 & - & - & - & - \\
\hline 2014 & 7 & 31 & 15 & 54.8 & 3.2 & 3.2 & 3.2 & 3.2 & 22.6 & 9.7 \\
\hline $2015^{a}$ & 5 & 26 & 21 & 69.2 & 26.9 & 3.8 & 0 & 0 & - & - \\
\hline 2016 & 4 & 39 & 11 & 28.2 & 51.3 & 20.5 & o & - & - & \\
\hline
\end{tabular}

${ }^{\mathrm{a}}$ Includes one non-dedicated boat survey where photo-identification images were taken.

from Tiumpan Head provided a systematic multi-year dataset for one part of the proposed NEL-MPA and provides solid support for a year-round occurrence by Risso's dolphins in recent years with sightings in every month. Gill \& Atkinson (1996) carried out land- and boat-based surveys at the Eye Peninsula in November/December 1995, recording groups of up to 30 Risso's dolphins and receiving opportunistic records during January and February 1996 that were also indicative of winter use of the region. More dedicated survey effort is needed particularly during the winter months to increase sample size and clarify dolphin occurrence during other seasons.

At least 131 Risso's dolphins were catalogued between 2010 and 2017, producing a MPS of 117 individuals identified from their right-side only. This is a comparable number to the 142 individuals identified around the Eye Peninsula by Atkinson et al. (1999) in 1995/96, although the latter study comprised almost three times the amount of boat survey effort $(358 \mathrm{~h})$ compared with the dataset presented in this paper $(115 \mathrm{~h})$ and consequently represents a much lower number of catalogued individuals per unit effort. The methods used by Atkinson et al. (1999) to catalogue individuals were not described and it is unclear whether PQ, DV or the use of left-only or right-only sides were taken into account when generating their value of 142 animals. The 2010-2017 discovery curve indicated that the population has not been fully sampled and the largest annual increase in the number of identified animals occurred recently in 2016. It is therefore likely that the true number of animals using the area is much higher than indicated by the results, particularly given evidence for movements of two individuals between the Hebrides and the Irish Sea (Stevens, 2014).

Since marine predators are wide-ranging mobile species, the assessment process for designating fixed-boundary MPAs as a long-term conservation measure usually focuses on demonstrating whether the area supports key life cycle stages of the species $(\mathrm{SNH}, 2017)$. In this paper we have provided multiple strands of evidence for persistent use of the east coast of Lewis by Risso's dolphins, including an 8-year spatiotemporal dataset showing long-term occurrence within the proposed NEL-MPA, and systematic photo-identification work that demonstrated re-sightings of some individuals in up to six out of the eight survey years and repeated intra-annual recaptures, despite relatively low amounts of survey effort. Longer-term recaptures of three individuals off east Lewis spanned periods of 10 to 12 years, representing the longest site fidelity evidenced for Risso's dolphins anywhere in UK waters to date (de Boer et al., 2013; Stevens, 2014).
Risso's dolphins feed on a range of benthic and diurnally migrating cephalopod species, with octopus (Eledone cirrhosa) dominating the prey identified in the stomachs of stranded animals from Scotland (MacLeod et al., 2014). Consequently, most daytime feeding probably occurs close to the seabed and is unlikely to be observed during visual boat surveys. However, we suggest that the importance of the area for foraging Risso's dolphins is strongly implied by their year-round occurrence over multiple years and by the documented site fidelity of individual animals to the east coast of Lewis.

Calf-positive scans were recorded from Tiumpan Head between April and October, with notable peaks at Tiumpan B in July, August and October when Risso's dolphin calves were present in $2.9-4.3 \%$ of the total scans carried out. We consider this likely to be a minimum representation, since small calves are not always easy to detect by shore-based observers employing a scan methodology. While the Shorewatch dataset did not distinguish between calves and juveniles, the dedicated boat survey work recorded definite calves (including neonates) in $37.5 \%$ of sightings. Gill \& Atkinson (1996) also reported the occurrence of calves (including neonates) off the Eye Peninsula during August and September 1995. The timing of the boat survey work (primarily in August and September) corresponds with the months that calves have also been recorded in Welsh waters (July to October: Baines \& Evans, 2012; Stevens, 2014), and may overlap with the calving period in UK waters. Both the shore and boat datasets therefore supported the use of the proposed NEL-MPA as a nursery ground by Risso's dolphins.

\section{Limitations and monitoring recommendations}

Due to weather limitations and platform availability, the boat survey study area covered only the southernmost portion of the proposed NEL-MPA, with little survey effort in Broad Bay and none at all in the northern part of the MPA. While much of that area was nominated for sand eel habitat $(\mathrm{SNH}$, 2014b), an assessment of Risso's dolphins northwards to the Butt of Lewis and further eastwards into The Minch would be beneficial in order to assess wider-scale dolphin occurrence and validate the importance of the proposed NEL-MPA relative to adjacent waters.

Published population studies of Risso's dolphins in UK waters have been limited by low temporal effort both intraand inter-annually, with most comprising opportunistic images from public sighting schemes or taken during general cetacean surveys aimed at wider regions (see Stevens, 2014). The few studies that have specifically targeted 
Risso's dolphins have generally consisted of multi-year studies comprising short seasonal surveys of only a few weeks (usually August to September; e.g. Atkinson et al., 1999; de Boer et al., 2013; this study). However, the Shorewatch data indicate that Risso's dolphins are present off Tiumpan Head year-round, and the collection of spatial and photo-identification data during other seasons would increase understanding of how and why dolphins are using the MPA, and whether the same individuals use the area year-round.

A number of limitations resulted in the photoidentification dataset being suboptimal for long-term population monitoring associated with a MPA. Notably, the discovery curve indicated that the Risso's dolphin population off east Lewis has not been fully sampled. The MPS of 117 individuals between 2010 and 2017 should be considered a conservative minimum, since not all dolphins were photoidentified during many encounters, young calves often did not bear sufficient markings to be catalogued and some individuals with suspected distinctive markings were not catalogued due to poor image quality.

In cetacean mark-recapture studies, emphasis is placed on quality-control procedures and on using only the best-quality images to estimate population size (Evans \& Hammond, 2004). Airoldi et al. (2015) limited their mark-recapture analysis of Risso's dolphins to images of PQ1-2. When similar quality-control was applied to the current study then the resulting MPS for most years was $\leq 25$ individuals, which was not considered sufficient for a robust mark-recapture analysis. The 8-year duration of this study and the low annual sampling effort (photo-identification images were acquired on only one to five surveys annually due to weather limitations) also increases the likelihood of undocumented changes in the appearance of individuals causing missed matches (i.e. false negatives) which violates the principles of mark-recapture analysis (Evans \& Hammond, 2004). Low sample effort also has implications for site fidelity analysis. For example, in most years some individuals were photographically captured on both the first and final survey, clearly indicating that the durations of intra-annual site fidelity reported here were limited by the temporal distribution of the survey effort. Incorporating increased amounts of survey effort during future monitoring programmes would greatly benefit multiple components of the data analysis presented here.

The behaviour of Risso's dolphins also presents challenges for photo-identification, since the species is naturally 'quiet', spending relatively long periods submerged and often moving unpredictably. Consequently, sustained (and sympathetic) effort is needed to systematically sample all animals within a group, and to ensure that even the more avoidant animals are representatively sampled to avoid heterogeneity of capture probabilities (Evans \& Hammond, 2004). The success of future photo-identification of Risso's dolphins in the NEL-MPA is likely to be maximized if time constraints during the surveys can be reduced to allow longer time with dolphin groups, for example via full-day boat surveys.

Future improvements to PQ would also improve interpretation and applicability of the data to population management. For example, there was evidence that low PQ adversely affected the identification of $\mathrm{DV}_{3}$ animals, presumably since small nicks were difficult to detect in poorer-quality images. An individual's DV affected the likelihood of recapture (most recaptures were of well-marked animals) and consequently it is apparent that PQ also has important implications for site fidelity analysis. Additionally, it should be expected that higher image quality would increase the potential for recaptures of individuals of all DV. Improved PQ would also facilitate other management-relevant analyses, such as the age-sex structure and stability of groups and the use of scarification levels to distinguish calves and juveniles (e.g. Hartmann et al., 2016).

\section{CONCLUSIONS}

While a number of study limitations are recognized that could be improved upon for future monitoring programmes in the area, the multi-year photo-identification and Shorewatch datasets reported here provide strong combined-support for the continued present-day and year-round use of the proposed NEL - MPA by a population of Risso's dolphins, including nursery groups. Future work should aim to clarify the underlying drivers for the spatio-temporal occurrence of the species in the area, via more detailed work on dolphin behaviour and habitat preferences. Wider-scale photo-identification comparisons of Risso's dolphins from the proposed NELMPA with other areas of the UK may increase understanding of wider-scale movements and population structure, and thus clarify the importance of the NEL-MPA in a UK-wide context.

\section{ACKNDWLEDGEMENTS}

We are grateful to everyone who supported the survey work including the WDC Shorewatch volunteers (particularly Janet Marshall and Steven Dodd) and WDC policy officer Katie Dyke, Lewis Mackenzie at Hebrides Fish 'n' Trips, Tim Atkinson, Nick Davies and the SNH Stornoway office (especially Roddy MacMinn). Scottish Natural Heritage granted the research licences (Nos. 10991 and 13371) to WDC for photo-identification work. Anna Inman and Emma Martin assisted with quality control grading of dolphin images. Thanks to two reviewers whose comments improved this manuscript.

\section{FINANCIAL SUPPDRT}

WDC, DEFRA, BBC Wildlife Fund, Elite Couriers, David Henriques, The J. \& J.R. Wilson Trust, The St Mary's Charity, The Pauline Meredith Charitable Trust and The Mackintosh Foundation provided funding for this fieldwork. Scottish Natural Heritage, Sea-Changers and The D'Oyly Carte Charitable Trust provided funding for Shorewatch.

\section{REFERENCES}

Airoldi S., Azzellino A., David L., Dhermain F., Di-Meglio N., Jimenez V., Jourdan J., Labach H., Lanfredi C., Remonato E., Rosso M., Roul M. and Scuderi A. (2015) Absolute abundance of Risso's dolphin (Grampus griseus) in the north western part of the Pelagos Sanctuary. Pelagos Sanctuary Convention No. 03/2014, Istituto Tethys /EcoOcean Institut/GECEM/Fondazione CIMA/GIS 3 M, 59 pp. 
Atkinson T., Gill A. and Evans P.G.H. (1999) A photo-identification study of Risso's dolphins in the Outer Hebrides, Northwest Scotland. European Research on Cetaceans 12, 102.

Baines M.E. and Evans P.G.H. (2012) Atlas of the marine mammals of Wales. CCW Monitoring Report, no. 68, 2nd edn, 139 pp.

de Boer M.N., Clark J., Leopold M.E., Simmonds M.P. and Reijnders P.J.H. (2013) Photo-identification methods reveal seasonal and longterm site-fidelity of Risso's dolphins (Grampus griseus) in shallow waters (Cardigan Bay, Wales). Open Journal of Marine Science 3, $66-75$.

Evans P.G.H., Anderwald P. and Baines M.E. (2003) UK cetacean status review. Report to English Nature and the Countryside Council for Wales. Oxford: Sea Watch Foundation, $160 \mathrm{pp}$.

Evans P.G.H. and Hammond P.S. (2004) Monitoring cetaceans in European waters. Mammal Review 34, 131-156.

Gill A. and Atkinson T. (1996) Risso's dolphins (Grampus griseus) in the coastal waters around the Eye Peninsula, Isle of Lewis, Scotland. Report to the Whale and Dolphin Conservation Society. Chippenham: WDC, $49 \mathrm{pp}$.

Hammond P.S., Lacey C., Gilles A., Viquerat S., Börjesson P., Herr H., Macleod K., Ridoux V., Santos M.B., Scheidat M., Teilmann J., Vingada J. and Øien N. (2017) Estimates of cetacean abundance in European Atlantic waters in summer 2016 from the SCANS-III aerial and shipboard surveys. Available at https://synergy.st-andrews. ac.uk/scans3/files/2017/04/SCANS-III-design-based-estimates-201704-28-final.pdf.

Hammond P.S., Macleod K., Samarra F., Swift R., Berggren P., Borchers D.L., Burt L., Paxton C.G.M., Cañadas A., Desportes G., Donovan G.P., Gilles A., Lehnert K., Scheidat M., Siebert U., Gillespie D., Leaper R., Gordon J., Hiby L., Lovell P., Kuklik I., Leopold M., Øien N., Ridoux V., Rogan E., Sequeira M., Skov H., Tasker M.L., Teilmann J., Van Canneyt O. and Vázquez J.A. (2013) Cetacean abundance and distribution in European Atlantic shelf waters to inform conservation and management. Biological Conservation 164, 107-122.

Hartman K.L., Fernandez M. and Azevedo J.M.N. (2014) Spatial segregation of calving and nursing Risso's dolphins (Grampus griseus) in the Azores, and its conservation implications. Marine Biology 161, 14191428 .

Hartman K.L., Visser F. and Hendriks A.J.E. (2008) Social structure of Risso's dolphins (Grampus griseus) at the Azores: a stratified community based on highly associated social units. Canadian Journal of Zoology 86, 294-306.

Hartman K.L., Wittich A. and Azevedo J.M.N. (2013) Show me your body and I tell you how old you are: a non-invasive method to define 6 life history classes in Risso's dolphins (Grampus griseus) using an identified trial population in the Atlantic. In Chen I., Hartman K., Simmonds M., Wittich A. and Wright A.J. (eds), Proceedings of the European Cetacean Society Workshop "Grampus griseus 2ooth anniversary: Risso's dolphins in the contemporary world", Galway, Ireland, 25 March 2012. European Cetacean Society Special Publication Series No 54, pp. 69-88.

Hartman K.L., Wittich A., Cai J.J., van der Meulen F.H. and Azevedo J.M.N. (2016) Estimating the age of Risso's dolphins (Grampus griseus) based on skin appearance. Journal of Mammalogy 97, 490-502.

Hodgins N.K., Dolman S.J. and Weir C.R. (2014) Potential hybridism between free-ranging Risso's dolphins (Grampus griseus) and bottlenose dolphins (Tursiops truncatus) off north-east Lewis (Hebrides, UK). Marine Biodiversity Records 7, e97.

Jefferson T.A., Weir C.R., Anderson R.C., Ballance L.T., Kenney R.D. and Kiszka J.J. (2014) Global distribution of Risso's dolphin Grampus griseus: a review and critical evaluation. Mammal Review $44,56-68$.

MacLeod C.D., Santos M.B. and Pierce G.J. (2014) Can habitat modelling for the octopus Eledone cirrhosa help identify key areas for Risso's dolphin in Scottish waters? Scottish Natural Heritage Commissioned Report, no. 530, 24 pp.

Paxton C.G.M., Scott-Hayward L.A.S. and Rexstad E. (2014) Statistica approaches to aid the identification of Marine Protected Areas for minke whale, Risso's dolphin, white-beaked dolphin and basking shark. Scottish Natural Heritage Commissioned Report, no. 594, 133 pp.

Reid J.B., Evans P.G.H. and Northridge S.P. (2003) Atlas of cetacean distribution in north-west European waters. Peterborough: Joint Nature Conservation Committee, $75 \mathrm{pp}$

Scottish Natural Heritage (2014a) Further advice to Scottish Governmen on the selection of Nature Conservation Marine Protected Areas for the development of the Scottish MPA network. Scottish Natural Heritage Commissioned Report No. 780.

Scottish Natural Heritage (2014b) Scottish MPA project - data confidence assessment for North-east Lewis MPA proposal. Report by Scottish Natural Heritage, 14 pp. Available at https://www.snh.scot/ sites/default/files/2017-11/Marine\%2oProtected\%2oArea\%20-\%2oData\% 2oconfidence $\%$ 2oassessment $\%$ 20-\%20North-east $\%$ 2oLewis\%2oMPA\%20 proposal.pdf.

Scottish Natural Heritage (2017) Marine Protected Areas in Scotland's seas. Guidelines on the selection of MPAs and development of the MPA network. Report by Scottish Natural Heritage, 73 pp. Available at http://www.gov.scot/Resource/Doc/295194/o114024.pdf.

Scottish Natural Heritage and the Joint Nature Conservation Committee (2012) Advice to the Scottish Government on the selection of Nature Conservation Marine Protected Areas (MPAs) for the development of the Scottish MPA network. Scottish Natural Heritage Commissioned Report, no. 547, 258 pp.

Stevens A. (2014) A photo-ID study of the Risso's dolphin (Grampus griseus) in Welsh coastal waters and the use of Maxent modelling to examine the environmental determinants of spatial and temporal distribution in the Irish Sea. MSc thesis. University of Wales, Bangor, UK.

Weir C.R., Pollock C., Cronin C. and Taylor S. (2001) Cetaceans of the Atlantic Frontier, north and west of Scotland. Continental Shelf Research 21, 1047-1071.

and

Würsig B. and Jefferson T.A. (1990) Methods of photo-identification for small cetaceans. Reports of the International Whaling Commission 12, 43-52.

\section{Correspondence should be addressed to:}

C.R. Weir

Whale and Dolphin Conservation, 38 St Paul Street, Chippenham, Wiltshire SN15 1LJ, UK and Ketos Ecology, 4 Compton Road, Kingsbridge, Devon TQ7 2BP, UK email: caroline.weir@ketosecology.co.uk 